\title{
TMEM135 is a Novel Regulator of Mitochondrial Dynamics and Physiology with Implications for Human Health Conditions
}

\author{
Heather K. Beasley ${ }^{1}{ }^{\mathbb{D}}$, Taylor A. Rodman ${ }^{1}$, Greg V. Collins ${ }^{2,3}$, Antentor Hinton, Jr. ${ }^{1, *}$ and Vernat Exil ${ }^{2,3, *}$ \\ 1 Department of Molecular Physiology and Biophysics, Vanderbilt University, Nashville, TN 37232, USA; \\ heather.k.beasley@vanderbilt.edu (H.K.B.); arabia@usf.edu (T.A.R.) \\ 2 Fraternal Order of Eagles Diabetes Research Center, Iowa City, IA 52242, USA; greg-collins@uiowa.edu \\ 3 Department of Pediatrics-Cardiology, Carver College of Medicine, University of Iowa, \\ Iowa City, IA 52242, USA \\ * Correspondence: antentor.o.hinton.jr@Vanderbilt.Edu (A.H.J.); Vernat-exil@uiowa.edu (V.E.)
}

check for

updates

Citation: Beasley, H.K.; Rodman,

T.A.; Collins, G.V.; Hinton, A., Jr.; Exil,

V. TMEM135 is a Novel Regulator of

Mitochondrial Dynamics and

Physiology with Implications for

Human Health Conditions. Cells 2021,

10, 1750. https://doi.org/10.3390/

cells10071750

Academic Editor: P.

Hemachandra Reddy

Received: 16 June 2021

Accepted: 6 July 2021

Published: 11 July 2021

Publisher's Note: MDPI stays neutral with regard to jurisdictional claims in published maps and institutional affiliations.

Copyright: (c) 2021 by the authors. Licensee MDPI, Basel, Switzerland. This article is an open access article distributed under the terms and conditions of the Creative Commons Attribution (CC BY) license (https:// creativecommons.org/licenses/by/ $4.0 /)$.

\begin{abstract}
Transmembrane proteins (TMEMs) are integral proteins that span biological membranes. TMEMs function as cellular membrane gates by modifying their conformation to control the influx and efflux of signals and molecules. TMEMs also reside in and interact with the membranes of various intracellular organelles. Despite much knowledge about the biological importance of TMEMs, their role in metabolic regulation is poorly understood. This review highlights the role of a single TMEM, transmembrane protein 135 (TMEM135). TMEM135 is thought to regulate the balance between mitochondrial fusion and fission and plays a role in regulating lipid droplet formation/tethering, fatty acid metabolism, and peroxisomal function. This review highlights our current understanding of the various roles of TMEM135 in cellular processes, organelle function, calcium dynamics, and metabolism.
\end{abstract}

Keywords: TMEM135; fission; mitochondrial dynamics; aging

\section{The Structure and Function of Transmembrane Proteins}

Transmembrane proteins (TMEMs) are essential for cellular structure and function [1,2]. Characterized by their protrusion through a membrane, TMEMs are generally composed of three domains with hydrophilic (extracellular and intracellular domains) and hydrophobic (bilayer domain) properties. The residues of the hydrophobic domain form a coil or helix that spans the lipid bilayer. Although biological membranes are fluid, TMEMs do not change their orientation within the membrane to perform their functions. Acting as membrane linkers, TMEMs instead undergo conformational changes to convey signals to secondary messenger systems. For example, some TMEMs have structures on their extracellular domain that are capable of binding with specific hormones in the extracellular environment $[3,4]$. Once a hormone molecule is bound, a conformational change at the binding site results in structural changes in the intracellular domain of the TMEM. These changes initiate a cascade of intracellular events that constitute a response to the external environment.

In addition to allowing cells gather information about the external environment, some TMEMs help control the transfer of solutes across membranes. These transmembrane transporters appear in clusters that create pores or channels within the membrane that can open and close under different conditions or in response to regulatory signals. For example, voltage-gated channels open and close in response to changes in the electrical potential across the membrane, whereas ligand-gated channels open and close in response to binding by specific signaling molecules or substrates [5-10]. A number of transmembrane transporters couple the inward movement of one solute to the outward movement of another [11]. Misfolding of transmembrane transporters is associated with a variety of clinical conditions $[1,2,12,13]$. 
There are several TMEMs in the mitochondria, including two well-studied TMEMs; TMEM70 and TMEM242. TMEM 70 is localized in the inner membrane of the mitochondria and functions as a facilitator of mammalian F1Fo ATP synthase [14-16]. Given the known role of TMEM70, mutations in TMEM70 lead to oxidative phosphorylation (OXPHOS) deficiencies linked to many mitochondrial diseases that present as neonatal mitochondrial encephalo-cardiomyopathy in humans [14,15,17-19]. Likewise, TMEM242 affects the arrangement of ATP synthase [20], whereas deletion of both TMEM70 and TMEM242 prevents the assembly of ATP synthase, thereby affecting complex I [20].

\section{The Discovery of Transmembrane Protein 135 (TMEM135)}

Very long-chain acyl-CoA dehydrogenase (VLCAD) is an enzyme that catalyzes the first step in the mitochondrial beta-oxidation of certain fatty acids. VLCAD deficiency is a well-documented condition in which pathogenic mutations in the ACADVL gene lead to severe physiological consequences, including cardiomyopathy, skeletal myopathy, encephalopathy, and sudden death in children and young adults [21-26]. TMEM135 was found to be elevated in the VLCAD-deficient mice. The VLCAD-deficient mouse model recapitulates the clinical phenotypes seen in VLCAD-deficient children. VLCAD-deficient mice display upregulation of critical regulators of mitochondrial biogenesis, such as peroxisome proliferation-activated receptor gamma coactivator-1 alpha (PGC- $1 \alpha$ ) and acyl-CoA synthase, an enzyme important for fatty acid biosynthesis and sarcolemmal fatty acid uptake [26]; TMEM135 was also elevated in VLCAD-deficient mice. Subsequent studies to further characterize TMEM135 revealed a function in adipogenesis and osteoblastogenesis [27]. The involvement in VLCAD deficiency suggests that TMEM135 may play a role in the regulatory feedback that controls mitochondrial fat metabolism. Further work in VLCAD-deficient mice and Caenorhabditis elegans (C. elegans) demonstrated that the metabolic role of TMEM135 in the enhancement of fat storage and mitochondrial function may link TMEM135 to other genetic networks, including insulin signaling [28-35].

\section{Structural Organization of the TMEM135 Gene and Protein}

The gene encoding TMEM135, also named peroxisomal protein 52 (PMP52) (https: / / www.ncbi.nlm.nih.gov/gene/ 65084 accessed on 15 June 2021), is located on chromosome 11 in humans (11q14.2) and chromosome 7 in mice. TMEM135 contains six alpha-helical transmembrane domains spanning amino acid positions 67-89, 96-115, 147-169, 300-322, and 332-354, respectively [11,12]. There are two predicted TMEM135 isoform products of alternative splicing. Isoform 1 , the canonical sequence, is 458 amino acids in length and has a molecular weight of 52,291 kDa. The shorter isoform 2, which is missing amino acids 133-154 from the canonical sequence, is 436 amino acids in length and has a molecular weight of $49,914 \mathrm{kDa}$. There are also two additional predicted isoforms containing a total of 330 and 319 amino acids, respectively. The four TMEM135 isoforms of homo sapiens are highly conserved across species, with a high degree of homology in Mus musculus, Rattus norvegicus, Bos taurus, Xenopus laevis, Macleaya cordata, Zeugodacus cucurbitae, Danio rerio, Gallus gallus, Oryctolagus cunuculus, and C. elegans (Figure 1).

Although TMEM135 is a transmembrane protein, it is unclear whether TMEM135 functions as a transmembrane channel. TMEM135 has yet to be crystallized, but the full-length wild-type protein is predicted to have its N-terminus on the outside of the membrane lipid bilayer and its $\mathrm{C}$-terminus on the inside. However, one study in an N-ethyl-N-nitrosourea (ENU)-induced mutant mouse line (FUN025) demonstrated that a point mutation (T > C) in the splice donor site adjacent to exon 12 altered the carboxy terminus, leading to a reverse orientation of the protein across the lipid bilayer [12]. Using the Clustal Omega multiple sequence alignment software (v1.2.4) [36], we aligned the homo sapien isoform 1 of the TMEM135 protein sequence with other mitochondrial TMEMs (Figure 2). 
A Macleaya cordata
Zeugodacus cucurbitae
Caenorhabditis elegans
Danio rerio
Xenopus laevis
Gallus gallus
Rattus norvegicus
Mus musculus
Bos taurus
Homo sapiens
Oryctolagus cuniculus

Macleaya cordata ungodacus Zeugodacus cucurbitae Caenorhabditis elegans Danio rerio Xenopus laevis

Rattus norvegicus Mus musculus

Bos taurus

Homo sapien Oryctolagus cuniculus

Macleaya cordata Zeugodacus cucurbitae Caenorhabditis elegans Danio rerio

Xenopus laevis

Gallus gallus

Rattus norvegicus

Mus musculus

Bos taurus

Homo sapiens Oryctolagus cuniculus

Macleaya cordata Zeugodacus cucurbita Caenorhabditis elegan Danio rerio

Xenopus laevis Gallus gallus

Rattus norvegicus

Mus musculus Bos taurus

Homo sapien Oryctolagus cuniculus

Macleaya cordata Zeugodacus cucurbita Caenorhabditis elegans Danio rerio Xenopus laevis

Gallus gallus

Rattus norvegicus

Mus musculus

Bos taurus

Homo sapiens Homo sapiens
Oryctolagus cuniculus
- - MSPACDG-TDTSTTTSCKCF - CEENEACNVDIDAKPDIQNCPHCRKLDHPSSFYFPF MAAMSKLFEYLIEND - VKCTNFFHKY - SCKTNS - . . . . . . . . . . . . . MGALSKLAHSLGQPILTATCYETIHTWNPDCNGAF . . . . . . . . . . . . . . . MAALS - ....... - KSIPHSCYELGHTWSSSCTAST

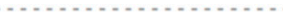

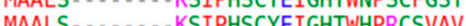

AALS - ....... KSIPHNCYEIGHTWNPSCRVSF . . . .

MAALS - . . . . - - KSIPHNCYEIGHTWHPSCRVSF

MAALS . . . . KSIPHNCYEIGHTWQPSCWLSF

MAALS - . . . . . KSIPHNCYEIGHTWHPSCRVSF - . . . . . . . . . . . . . *

TSDFRSEKDVEKLWRIVIASAKGFSIGAGLKGGLALFSVLTRLKKGRLSASORKAGMVS . . . . LIITYKFLI SNMKYFA . . . . . . PIIGLPLLLRIR - SLNKKVLL . . . . . FDALPVGLIFSLKTYA - . . . . - SFYLITNVVSKR - -GRLDKINW - . . . . . . . . . LQVTAGALEVSFKIYA . . . . . . PLYLIAAILRRR - - KK . . DYYK . . . . … . . - LQITQGAMEESFKIYA - . . . . . PLYLVAAILRRK - - NL - DYYV . ..... - . LHVTQGALAESLRIYG - . . . . . . TLYLIAAILRKR - -KL - DYYL . . . . ....... - LQITWGALEESLRIYA - . . . . PLYLIAAVLRKR - -KL - EYYL . . . .

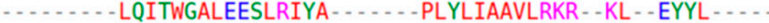

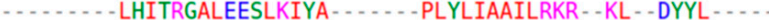
- DLYIAAILRKR -KL - DYYL - . . . . . . . LQITGGALEESLKIYA . . . . . . PLYLIAAILRKR - - KL . . DYYL . . . .

NSEAIVRAFKETLRYGLFLGSFAGTFVTVDELIAALGGHRRTASWRALLAGAIA . . . 169 - - - ATL - OYYVEAVMTGTAIGWSVIVSICISRHI - -FGKFTYLSTLLLPTFVGSFGOY - - KKFGIDVCQSSLFLVTNMCFFLILLCKFRKW - - LGFFTPITMGLVSSILASGIAI - . - KRLLPEILOSTSFLTANGGLYIAFFCILRRL - - LGRFYSWSAGFGAALPASYIAI - HKLLPELLOSTSFLTANGSLYIAFFCILRKL - LGRFYFWTPGFGAALPASYAAI HKLIPEILOSTSFL TANGTLYIACFCILRKL - LGKFYFWSPGFGAALPASYMAI . . . . YKLIPEII SSASFL TANGALYITFFCVLRKI - LGKFYSWTPGFGAALPASYVAI - . - YKLLPEILOSASFL TANGALYITFFCILRKI - - LGKFYSWTPGFGALPASYVAI - - - - HKLLPEILQSASFLTANGALFMAFFCILRKI - - LGKFYLWSPGFGAALPASYVAI - HKLLPEILOSASFLTANGALYMAFFCILRKI - - LGKFYSWTPGFGALPASYVAI - - - - HKLLPEILQSASFLTANGALYIAFFCTLRKI - - LGKFYSWTPGFGAALPASYMAI

$$
: \quad::
$$

. . . . . . . . . . . . . . . . . IVPSPRV - . . . . . . . . . HRLFAITIFOCTLESLIIQKKT . . . . VLAKLIA . . . NSSLL LVEKKSR - . . . . . . . . . . . . RPALALYLINLASETYYRHLA . NHGYV LIERKSR - . . . . . . . . . . . . . LIERKSR . . . . . . . . . . . . . . . RGLLTIYMANQATEALFRMGV . . . TRGYI IERKSROGMNWLLTLLLGPLCALGLFGCRRGLLTIYMANQATETLFRMAV - . . - ARGAI LIERKSR - . . . LIERKSR - . . . . . LIERKSR

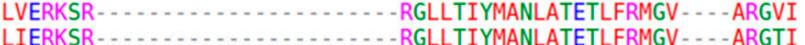
LIERKSR - . . * :

KPLTWSHGDIFLMCLSSSQILSAYILKPDSLPPSYNSFLNTHA - . - - GKHSAILQGI . . . R - . . . . . . FMFMCCSAL . . . . . . LNAKRRKAFNGFWL MEP . . . . . . . . . . . . . T - - MHTYGECIPFGIGLMLFT - -WLQSIGRLPKSFNGFMNVALKSNVSENLINEK-

K - - PMKHGEVLLFCLTASLYM - - FFFR - - - CKDGLNGFAFSALKFIVGKEEIPTHSCLAE K - PIRHGEVLLFCITSALYM - - FFFR - - CRDGLKGFAFSALKFIVGKEEIPAHALLPE K - - PLRHGEVLLFCITSALFM - FFFR - - CKDGLKGFTYSALKFIVGKEEIPTHSFSPE T - - TLRNGEVLLFCITAAMYM - - FFFR - - - CKDGLKGFTFSALRFIVGKEEIPTHSYSPE T - - TLRNGEVLLFCITAAMYM - - FFFR . . - CKDGLKGFTFSALRFIVGKEEIPTHSYSPE T- TLRNGVLLFCITAAMYM - FFFR - -CKDGLKGFTFSALRFIVGKEEIPTHSYSPE T- - TLRNGEVLLFCITAAMYM - - FFFR - - - CKDGLKGFTFSALRFIVGKEEIPTHSFSPE T - - SLRNGEVLLFCITAAMYM - - FFFR - - - CKDGLKGFAFSALRFIVGKEEIPTHSYSPE $::$
$: \quad:{ }^{*}$

Figure 1. Conts. 
B

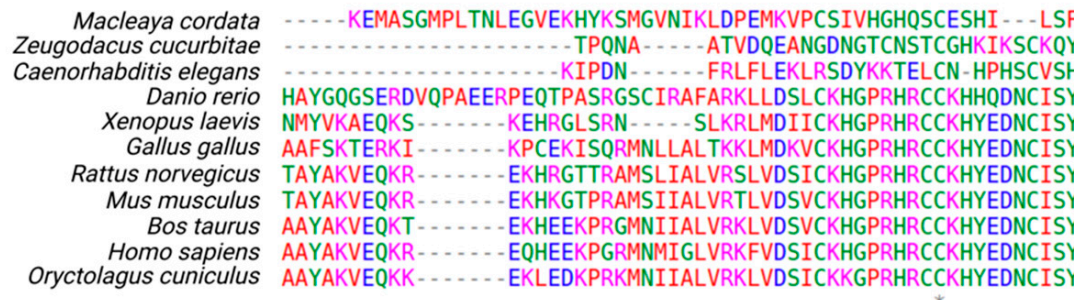

Macleaya cordata LVQAYARALPVYLPVYLFPALIVHRODLMKRPYSIL . . . . . . . . GKGLFGTARSSLFLS Zeugodacus cucurbitae ALOGIRNFMMTGLALDAIKMLLANVPADVNGFTAKL Caenorhabditis elegans SVESFAKNMTFGLTASSVLTVIRNVRTI KKNPLNLITLLVSKENLKLPIFAG _. . . FLPF Danio rerio CVKGFIRMFSVGYLIOCCLKVPSAFRQAFTKPSRLLWLLYNKENFQLGAFLG - . - SFVS Xenopus laevis CIKGFIRMFSIGYLIQCCLRIPSTFRHLFTKPSRLLSLFYNKENFQLGAFLG - - - S SFVS Gallus gallus CIKGFIRMFSIGYLIQCCLRIPSTFRHLFTKPSRLLSLFYNKENFQLGAFLG - . . - SFVS

Rattus norvegicus CIKGFIRMFSVGYLIQCCLRIPSAFRHLFTEPSRLLSLFYNKENFOLGAFLG - . . SFVS

Mus musculus CIKGFIRMFSVGYLIOCCLRIPSAFRHLFTEPSRLLSLFYNKENFQLGAFLG ... SFVS Bos taurUS CIKGFIRMFSVGLIOCCLRIPSAFRHLFTQPSRLLSLFYMKENFOLGAFLG - - - SFVS 列 Oryctolagus cuniculus CIKGFIRMFSVGYLIQCCLRIPSAFRHLFTQPSRLLSLFYNKENFQLGAFLG - . - SFVS

Macleaya cordata VYCATAWLVMWTCILFRTFKRCNIPMVAMGTFPPGLALAIEKKSRRIEISLYCFARAI Zeugodacus cucurbitae IYRLLHCYFNRNFGGDSQLK Caenorhabditis elegans IFNATRCSLNRVKYYPPVLN - . . . . NVFSAGLASVAMA - . FYPTVSIAMYCLWKAI Danio rerio IYKGTSCLIRWMRNLDDELH ...... ALIAGFLAGTSMF . . . FYKSTTISMYLFSKLV Xenopus laevis IYKGTSCFLRWVRNLDDELH - ....... ALVAGFLAGISMM . . FYKSTTISMYLASKLV Gallus gallus IYKGTSCFLRWVRNLDDELH ........ ALVAGCLAGISMM . . FYKSTTISMYLASKLV

Rattus norvegicus IYKGTSCFLRWIRNLDDELH - . . . . AIVAGFLAGVSMM . . - FYKSTTISMYLASKLV -

Mus musculus IYKGTSCFLRWIRNLDDELH - . . . . AIVAGFLAGVSMM . . - FYKSTTISMYLASKLV Bos taurus IYKGTSCFLRWVRNLDDELH - . . . . AIIAGFLAGVSMM . . - FYKSTTISMYLASKLV -

Homo sapiens IYKGTSCFLRWTRNLDDELH _.... AI IAGFLAGISMM . . - FYKSTTISMYLASKLV Oryctolagus cuniculus IYKGTSCFLRWIRNLDDELH - . . . - AIIAGFLAGVSMM - . - FYKSTTISMYLASKLV .

ESFFTCMVDAGYFPRSKKLNRADVVIFSLSTAIIMHCYAQ *

Macleaya cordata SWKELTTYLSAERFGGSFEWIORL-PCROIIYPAAVAYLVHTYALRKRHASNLGGIVVDG Caenorhabditis elegans . . . . ETVYFDLVDRGYLPKFKN - . GEVILYAITTGYVLWNAVV . . . . . . . . EPRA Danio rerio

Xenopus laevis - ETMYFKGIEAGKCPYFPH ADSVTYAVSTAVCFHAAVM - . - EV

Gallus gallus .... ETIYFKGIEAGKVPYFPH . . ADSVIYAISTSICFOAAVM . . . . . . . EVON

Rattus norvegicus …. ETMYFKGIEAGKVPYFPO - . ADTIIYSISTAICFHAAVM ............. EVON

Mus musculus … ETMYFKGIEAGKVPYFPQ - ADTIIYSISTAICFHAAVM ........ EVQN Bos taurus -... ETMYFKGIEAGKVPYFPH - . ADTIIYSISTAICFQAAVM . . . . . . . . EVQT

Homo sapiens .... ETMYFKGIEAGKVPYFPH . . ADTIIYSISTAICFQAAVM . . . . . . . . . . EVQ Oryctolagus cuniculus .... ETMYFKGIEAGKVPYFPH - . ADTIIYSISTAICFQAAVM - . . . . . . - EVQT : : :

Macleaya cordata FRSKYLNVLDWVFGVPPP . . . . . . . KCETPRDKHN - . . . . . . . . . . . . . Zeugodacus cucurbitae ITNNYVKFVHA .......................... NVERIEQLMAQCTPTL . . . Caenorhabditis elegans IRRGYLNFLFGLVGGKISLFNRRLYDHFGFVS-RDVYTKIPEFDPKYAMINPMLYMPLVE Danio rerio LRPSYWKFLLRLTKGRFALMNRKVLDVFGTEASKNFGNFTPKLDPRFVLCPVDMDVQLG Xenopus laevis LRPSYWKFLQRLTKGRFALMNRKALDVFDSEASKNFNNFVPKLDPRFCIVKPELPLDFS Gallus gallus LRPSYWKFLLRLTKGRFALMNRKVLDVFGTEASRNFKDFTPKLDPRYTVVPPELPLELS

Rattus norvegicus LRPSYWKFLLRLTKGRFALMNRKALDVFGTGASREFHNFIPRLDPRYTVVTPELPIDFS

Mus musculus LRPSYWKFLLRLTKGRFALMNRKALDVFGTGASREFHNFIPRLDPRYTVVTPELPIDFS Bos taurus LRPSYWKFLLRLTKGRFAVMNRKVLDVFGTGASKNFPDFTPRLDPRYTTVTPELPIEFS

Homo sapiens LRPSYWKFLLRLTKGKFAVMNRKVLDVFGTGASKHFQDFIPRLDPRYTTVTPELPTEFS Oryctolagus cuniculus LRPSYWKFLLRLTKGKFAVMNRKVLDVFGTSASKHFQDFTPRLDPRYTTVPPELPTEFS-

Figure 1. Comparison of the sequence homology of TMEM135 (A,B) across 11 different species using Clustal Omega Multiple Sequence alignment software (v.1.2.4). Clustal Omega designates the following colors for amino acid groups: AVFPMILW-Red: Small (small + hydrophobic [includes aromatic -Y])DE-Blue: Acidic, RHK-Magenta: Basic -H,STYHCNGQ -Green: Hydroxly + sulfhydryl + amine + G Others-Gray: Unusual amino/imino acids etc. (Accession numbers for TMEM135 species: OUZ99344.1, JAD00441.1, NP_508800.2, NP_001082887.1, NP_001085541.1, XP_040514949.1, NP_001013918.1, NP_082619.3, AAI03394.1, NP_075069.3, and XP_002708692.1 ) [36]. Figure created with BioRender.com (accessed on 15 June 2021). 
TMEM70

TMEM70

TMEM135

TMEM242

TMEM70

TMEM135

TMEM242

TMEM70

TMEM135

TMEM242

TMEM70

TMEM135

TMEM242

TMEM70

TMEM135

TMEM242

TMEM70

TMEM135

TMEM242

TMEM70

TMEM135

TMEM242
$-M L F-$

LHKLLPEILQSASFLTANGALYMAFFCILRKILGKFYSWTPGFGAALPASYVAILIERKS -QPASGLEAPGSTNDRLFLVKG-

GIFLGTVA

:*

------------------- LALGSPWAVELPLCGR----------RTALCAAAA -RRGLLTIYMANL-----ATETLFRMGVAR----------GTITTLRNGEVLLFCITAAMY AAGMLAGF ITTLSLAKKKSPEWFNKGSMATAALPESGSSLALRALGWGSLYAWC------

$: \quad *$

---------LRGP-----RASVSRASSSSGPSGPVAGWSTGPSGAARLLRRPGRAQIPVY MFFFRCKDGLKGFTFSALRF IVGKEEIPTHSF SPEAAYAKVEQKREQHEEKPGRMNMIGL $------G V G V I S F A V W K---A L G V H S M N D--F---------------------------1$ : $\quad$. .

WEGYVRFLNTPSDKSEDGRLIYTGNMARAVFGVKCFSYSTSL-IGLTFLPYIFTQNN--VRKFVDSICKHGP---R-------HRCCKHYEDNCISYCIKGF IRMF SVGYLIQCCLRIP

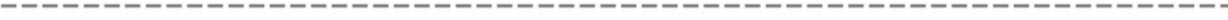

-AISES--VPLPIQIIFY--------GIMGSFTVITP---V----------LLHFITKGY SAFRHLFTQPSRLLSLFYNKENFQLGAFLGSFVSIYKGTSCFLRWIRNLDDELHAI IAGF $---\mathrm{R}------\mathrm{S}--$ - KMOS IFPTIPKNSESAVEWEETLKSK: . * *

V----IRLYHEATTDTYKAITYNAMLAETSTVFHQNDVK IPDAKHVFTTFYAKTKSLLVN LAGISMMFYKSTTISMYLASK----LVETMYFKGIEAGKVPYFPHADTI IYSISTAICFQ

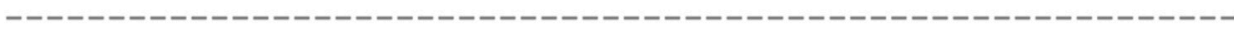

$\begin{array}{rll}\text { TMEM70 } & ------- & 260 \\ \text { TMEM135 } & \text { ELPTEFS } & 458 \\ \text { TMEM242 } & ------- & 141\end{array}$

Figure 2. Comparison of the conserved sequence homology of TMEM135 (homo sapien) [NP_075069.3] with TMEM70 (homo sapien) [AAH02748.2] and TMEM242 (homo sapien) [NP_060922.2] using Clustal Omega Multiple Sequence alignment (v.1.2.4.) [36]. Clustal Omega designates the following colors for amino acid groups: AVFPMILW-Red: Small (small + hydrophobic [includes aromatic-Y])DE-Blue: Acidic, RHK-Magenta: Basic -H,STYHCNGQ -Green: Hydroxly + sulfhydryl + amine + G Others-Gray: Unusual amino/imino acids, etc. Figure created with BioRender.com (accessed on 15 June 2021).

\section{TMEM135 is a Regulator of Mitochondrial Dynamics}

The mitochondrion is the only organelle in animals that contains its own self-replicating genome. Mitochondrial DNA encodes 13 essential components of the oxidative phosphorylation (OXPHOS) system, although many mitochondrial proteins are encoded by the nuclear genome. Once thought to be rigid structures, mitochondria migrate through the cell to fuse, divide, and to undergo regulated turnover [37]. Mitochondrial dynamics include the movement of mitochondria along the cytoskeleton and changes in mitochondrial morphology, distribution, and connectivity, which are mediated by tethering, fusion, 
and fission events [36-42]. At steady state, fission and fusion events are balanced to maintain mitochondrial morphology and function [39]. When mitochondria undergo fusion, GTPases, mitofusin 1 (MFN-1), and mitofusin 2 (MFN-2) regulate fusion of the outer mitochondria, whereas optic atrophy 1 (OPA-1) regulates fusion of the inner membranes [39-48]. Mitochondrial fission is mediated by the cytosolic dynamin family member dynamin-related protein 1 (DRP1) [43-45], which is recruited from the cytosol to form spirals around mitochondria that constrict and sever the inner and outer membranes.

TMEM135 has an indirect, yet integral role, in mitochondrial metabolism and membrane potential, where it is thought to regulate mitochondrial fission and fusion $[6,37,38,45-51]$. Disruption of TMEM135 function in mice can tip the fusion-fission balance towards fusion, leading to an increase in the size and a decrease in the number of mitochondria in cells [12,52]. Lee et al. demonstrated that TMEM135 colocalizes with oligomerized DRP1 and proposed that TMEM135 acts as a regulator of mitochondrial fission by activating DRP1 [12]. In C. elegans, overexpression of TMEM135 increases mitochondrial fragmentation and membrane potential, whereas loss of TMEM135 decreases the mitochondrial membrane potential and the rate of oxygen consumption [11]. However, the definitive role of TMEM 135 in oxidative phosphorylation and mitochondrial dynamics continues to be poorly understood.

\section{TMEM135 and Peroxisomal Transport}

Faust et al. first described TMEM135 as a peroxisomal protein in Drosophila melanogaster (fly base isoform CG11737) [53]. TMEM135 is a target of the liver X transcription factor in human liver cells and has homology with the Tim17 family of proteins, which mediate protein translocation across mitochondrial membranes [53]. Loss of TMEM135 in hepatocytes reduces concentrations of peroxisomal matrix enzymes that help break down long-chain fatty acids (LCFAs). Despite these findings, little is understood about how TMEM135 is involved in fatty acid beta-oxidation and enzyme transport in peroxisomes. Generally, mitochondria favor the oxidation of short-chain and medium-chain fatty acids $(<\mathrm{C} 12)[54]$, although palmitate (C16) is the preferred substrate for fatty acid oxidation in the myocardium. Mitochondria and peroxisomes both oxidize LCFAs (C14-C18), whereas only peroxisomes oxidize verylong-chain fatty acids (VLCFAs, >C20) [54]. Renquist et al. used electrophoretic mobility shift assay (EMSA) and chromatic immunoprecipitation (ChIP) analysis to demonstrate that the human TMEM135 promoter contains a liver $X$ receptor (LXR) response element that binds LXRs and mediates LXR-induced transcription [12,55]. This response element was notably not found in murine cells [56]. Furthermore, in human HepG2 cells, decreased expression of TMEM135 caused triglyceride accumulation regardless of diminished lipogenic gene expression, suggesting a potential role for TMEM135 in beta-oxidation.

To determine its physiological importance, TMEM135 was knocked down via siRNA in the livers of fed and fasted C57BL/6 mice. Consistent with increased fatty acid uptake and beta-oxidation, fasting augmented hepatic fatty acid and NADH concentrations in control mice. Compared with the control mice, fasted TMEM135-knockdown mice displayed a further increase in hepatic fatty acid concentrations and a significant decrease in NADH concentration, suggesting impairment of peroxisomal beta-oxidation [55]. The peroxisomal contribution to overall LCFA beta-oxidation becomes greater during physiological states of increased fatty acid load, such as fasting, which might partly explain why TMEM135 protein levels were increased in heart and skeletal muscle during fasting and cold stress in mice [1]. The observed increases in linoleic acid and total fatty acid levels in fasted TMEM135knockdown mice are consistent with an impairment of beta-oxidation. Despite some evidence suggesting that TMEM135 localization in the peroxisome may signal peroxisome impairment, there is no known role for TMEM135 in mitochondrial biogenesis, impairment, and/or beta-oxidation [9]. Further analysis of the hepatic NADH and ketone concentrations is needed to confirm peroxisomal beta-oxidation. Renquist et al. demonstrated that TMEM135 mRNA expression is induced by peroxisome proliferation-activated receptor (PPAR) agonists and that the TMEM135 promoter is bound by PPAR [55], indicating that TMEM135 is also a PPAR target gene. These findings suggest that TMEM135 may be 
a potential therapeutic target in the treatment of age-related diseases associated with peroxisome dysfunction.

\section{Potential Physiological Roles of TMEM135}

In C. elegans and mice, TMEM135 is ubiquitously expressed in a variety of tissues, with the highest expression found under conditions of cold and fasting stress [57,58]. In C. elegans, TMEM135 is involved in fat storage and longevity regulation [11]. TMEM135 is expressed in the nucleus, sarcoplasmic reticulum, and plasma membrane, localizing with lipid droplets, peroxisomes, and mitochondria [11,12,32,49,55]. TMEM135 can also be found within mitochondrial endoplasmic reticulum contact sites (MERCs) [11,52,53,55]. MERC sites are specialized contact sites that are thought to be enriched with proteins involved in mitochondrial calcium $\left(\mathrm{Ca}^{2+}\right)$ flux, lipid transfer, and morphology [59-61]. Therefore, not only can TMEM135 participate in fission, similar to DRP1 [62], but TMEM135 may also be involved in lipid transport across the mitochondrial membrane within MERC sites [27,63,64]. Any fluctuation in MERC sites that TMEM135 directly or indirectly regulates may serve as a mechanistic link between TMEM135 defects and disruption of cell metabolism.

As shown in our schematic (Figure 3), we hypothesize a role of TMEM135 in fission. Breckenridge et al. showed that $\mathrm{Ca}^{2+}$ influx into the mitochondria stimulates DRP1dependent mitochondrial fission and a subsequent release of cytochrome c release [65]. It cannot be ruled out that TMEM135 plays a role in regulating the balance between mitochondrial fusion and fission since it has been proposed that TMEM135 activates DRP1 [12]. Additional investigation is necessary to define the role of TMEM135 in fission (Figure 4). We have summarized the potential physiological roles of TMEM135 in Table 1.

Table 1. TMEM135 has many implications in disease and many potential physiological roles. Using The Human Protein Atlas Databank [67] and literature, we show the predicted locations of TMEM135, expression in human tissue, known interactions with organelles and vesicles, the physiological role of TMEM135 [68], and the implication of TMEM135 in human disease.

\begin{tabular}{|c|c|c|c|c|}
\hline Predicted Location & Major Expression in Tsue & $\begin{array}{l}\text { Known Interactions with } \\
\text { Organelles/Vesicles }\end{array}$ & Physiological Role & $\begin{array}{l}\text { Implication in } \\
\text { Human Disease }\end{array}$ \\
\hline $\begin{array}{ll}\text { - } & \text { Vesicles [66] } \\
\text { - } & \text { Membrane [66] }\end{array}$ & $\begin{array}{l}\text { - Medium expression } \\
\text { in: Cerebral cortex, } \\
\text { Cerebellum } \\
\text { Hippocampus, } \\
\text { Caudate } \\
\text { Nasopharynx, } \\
\text { Bronchus, Lung, } \\
\text { Duodenum, Small } \\
\text { intestine, Cervix, } \\
\text { uterine, and } \\
\text { Adipose tissue [66] } \\
\text { Low expression in: } \\
\text { Thyroid gland, } \\
\text { Parathyroid gland, } \\
\text { Adrenal gland, Oral } \\
\text { mucosa, Salivary } \\
\text { gland, Stomach, } \\
\text { Colon, Rectum, } \\
\text { Liver, Gallbladder, } \\
\text { Kidney, Urinary } \\
\text { bladder, Testis, } \\
\text { Epididymis, Seminal } \\
\text { vesicle, Vagina, } \\
\text { Ovary, Fallopian } \\
\text { Tube, Endometrium, } \\
\text { Placenta, Breast, } \\
\text { Smooth muscle, } \\
\text { Skin, Appendix, and } \\
\text { Soft tissue [66] }\end{array}$ & $\begin{array}{ll}\text { - } & \text { Lipid Droplets [11] } \\
\text { - } & \text { Mitochondria [11] } \\
\text { - } & \text { SR/ER [11] } \\
\text { - } & \text { Peroxisome [52] } \\
\text { - } & \text { Lysosome [65] } \\
\text { - } & \text { Proposed that } \\
& \text { TMEM135 may } \\
& \text { interact with MERCs }\end{array}$ & $\begin{array}{ll}\text { - } & \text { Cholesterol } \\
\text { transport; }[67,69] \\
\text { - } & \text { Intracellular } \\
\text { cholesterol } \\
\text { distribution; }[67,69] \\
\text { - } \quad \text { Fat storage and } \\
\text { longevity } \\
\text { regulation [67,69] } \\
\text { Regulation of } \\
\text { ciliogenesis } \\
\text { (cholesterol } \\
\text { dependent) [67,69] }\end{array}$ & 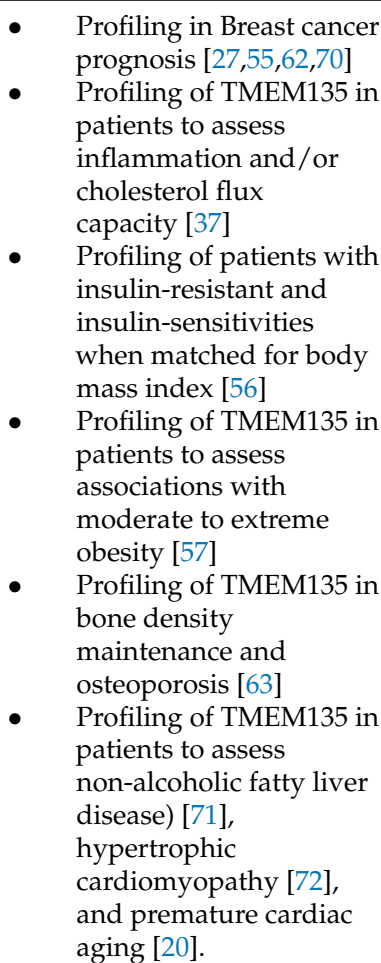 \\
\hline
\end{tabular}




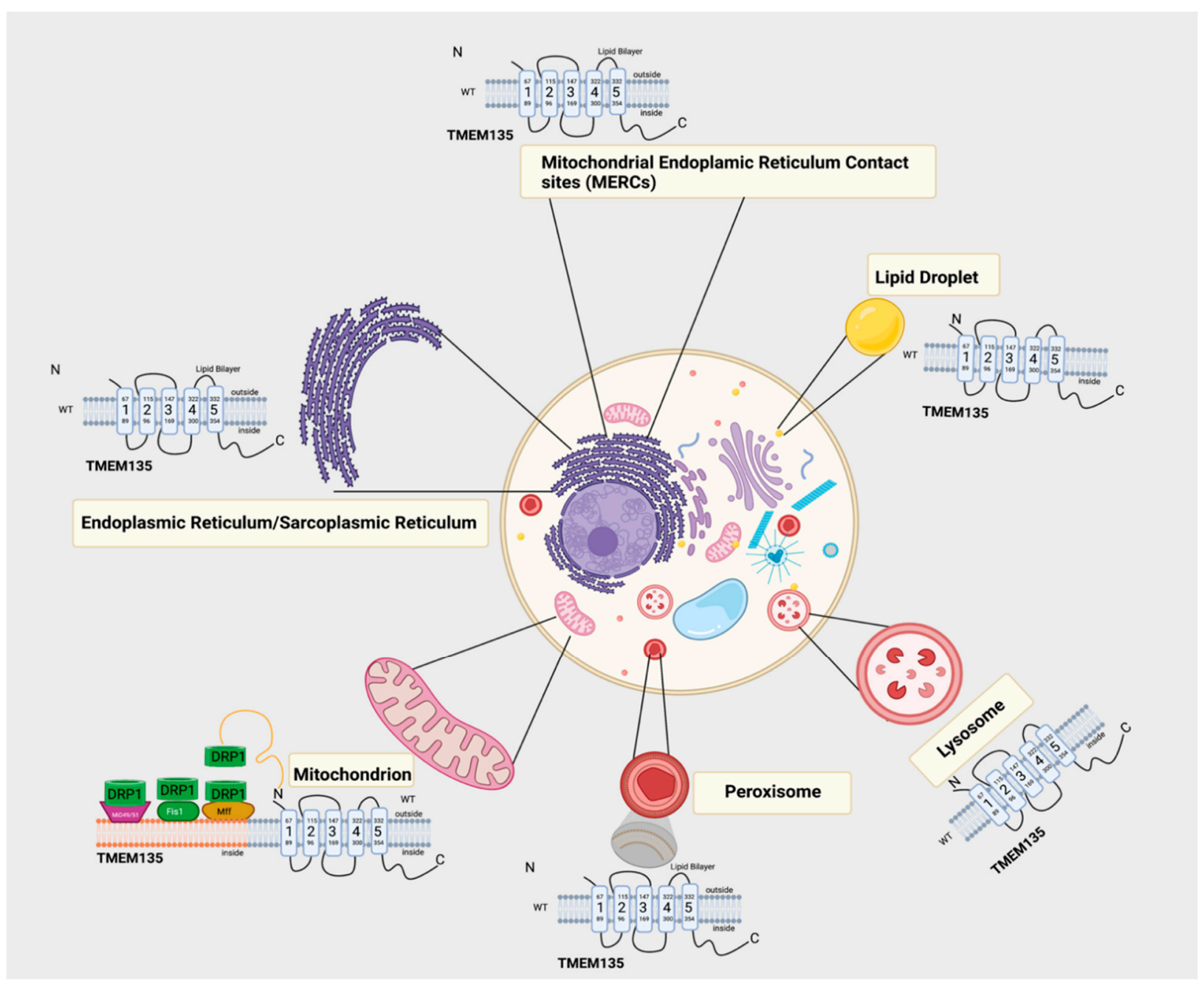

Figure 3. This plausible model of TMEM135 demonstrates the many interactions for TMEM135 in several organelles, including the mitochondria [11] and the mitochondrial endoplasmic reticulum contact sites (MERCs). Additionally, TMEM135 is also a peroxisomal protein [66]. TMEM135 has been shown to co-localize with DRP1 as referenced in Wei Lee et al., 2016 [12]. Here, we show the plausible interaction between TMEM135 and DRP1 in the mitochondria and TMEM135 in the peroxisome [53], lysosome [66], lipid droplets [11], and the endoplasmic reticulum/ sarcoplasmic reticulum (ER/SR) [11]. Figure created with BioRender.com (accessed on 15 June 2021). 


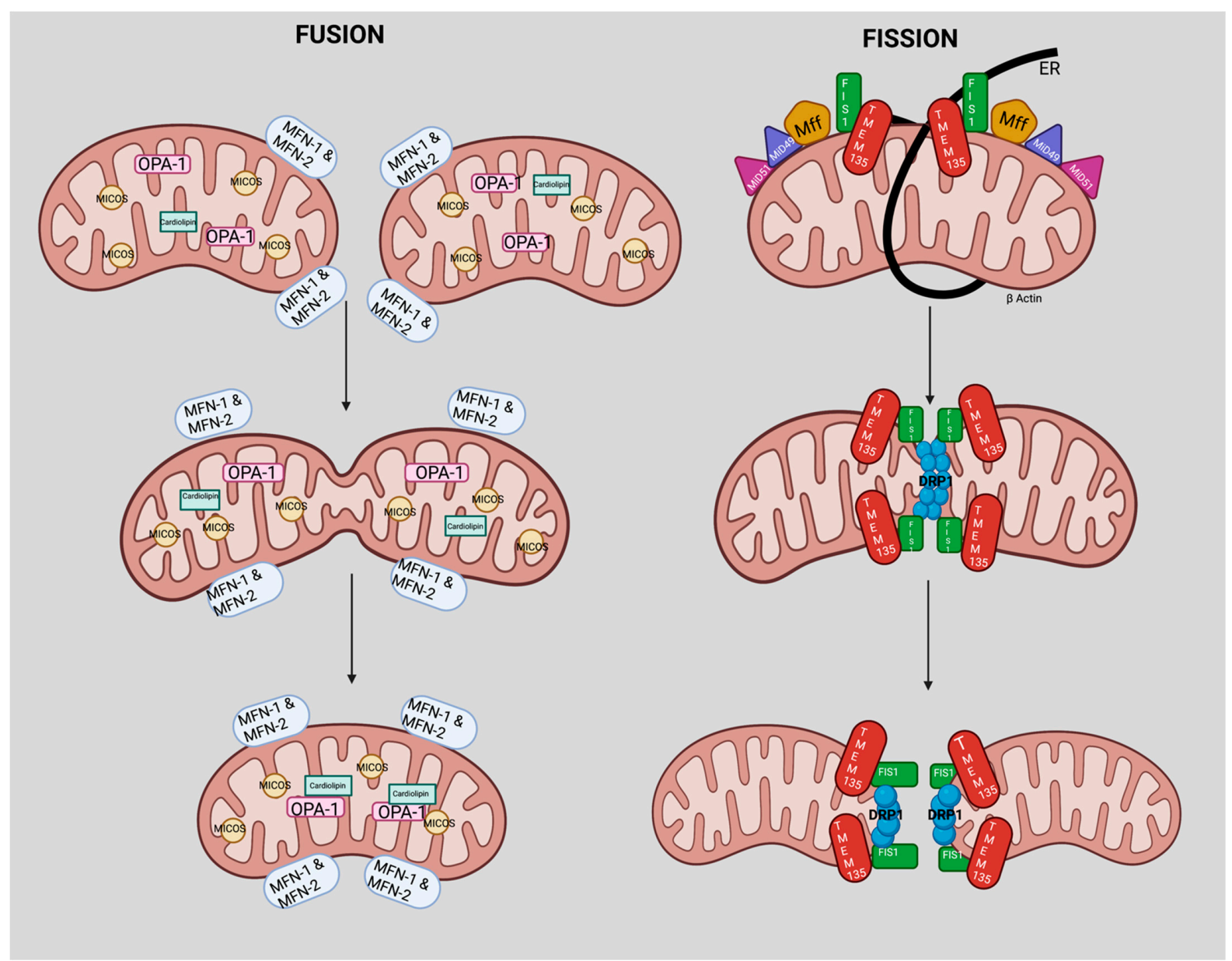

Figure 4. We hypothesize a role of TMEM135 in fission due to $\mathrm{Ca}^{2+}$ influx into the mitochondria and stimulation of DRP1dependent mitochondrial fission. Mitochondrial dynamics are split into two processes: Fusion and Fission. Mitochondrial fusion is coordinated by Mitofusin 1 (MFN-1) and Mitofusin 2 (MFN-2) [light blue color], Optic Atrophy 1 (OPA-1) [light pink], Mitochondrial contact site and cristae organizing system (MICOS) [light yellow], and Cardiolipin [light green]. Mitochondrial fission proteins are coordinated by Mitochondrial Fission 1 protein (FIS1) [green], Mitochondrial dynamic protein of $51 \mathrm{kDa}$ homolog (MiD51) [magenta] and Mitochondrial Fission Factor of 49kDA homology (MiD49) [purple], Mitochondria fission factor (Mff) [dark yellow], Transmembrane Protein 135 (TMEM135) [red] on the outer membrane of the mitochondria; whereas, Dynamin-1-like protein 1 (DRP1) [blue] is located in the inner membrane of the mitochondria. The endoplasmic reticulum (ER) [black] is represented in the fission process. It cannot be ruled out that TMEM135 plays a role in regulating the balance between mitochondrial fusion and fission since it has been proposed that TMEM135 activates DRP1 [12]. Figure created with BioRender.com (accessed on 15 June 2021).

\section{Potential Role of TMEM135 as a Regulator of Calcium Dynamics}

The mitochondria and endoplasmic reticulum (ER) play essential roles in maintaining $\mathrm{Ca}^{2+}$ homeostasis and lipids. In addition to storing $\mathrm{Ca}^{2+}$, mitochondria can accumulate large amounts of $\mathrm{Ca}^{2+}$ to maintain mitochondrial energy metabolism [73,74]; therefore, it is essential to investigate the function of TMEM135 within these homeostatic mechanisms. As mentioned earlier, the mitochondria are linked to the ER by MERCs, which enable mitochondria and ER to exchange $\mathrm{Ca}^{2+}[74,75]$. Any dysregulation or modulation of $\mathrm{Ca}^{2+}$ signaling and flux can affect critical cellular networks and structures, including MERC sites [76-78]. Notably, $\mathrm{Ca}^{2+}$ functions directly and as a second messenger in almost every physiological process-especially in the mitochondria. It should also be noted that $\mathrm{Ca}^{2+}$ regulates several cellular processes, including apoptosis, signal transduction, and transcriptional regulation [79-81]. Given TMEM135 is involved in mitochondrial dynamics $[12,82,83]$, we speculate that TMEM135 may also regulate $\mathrm{Ca}^{2+}$ flux, $\mathrm{Ca}^{2+}$ uptake, 
and $\mathrm{Ca}^{2+}$-dependent transcription factors and kinases. TMEM135 may regulate several transcription factors that have integral roles in maintaining $\mathrm{Ca}^{2+}$ dynamics in the cell.

C. elegans studies revealed that TMEM135 could also regulate Forkhead box O (FOXO), FoxO, expression $[11,84]$. Elevated nuclear expression of FoxO and its target genes can contribute to muscle wasting and cell death [84]. FoxO transcription factors can also contribute to cardiac growth, cardiac remodeling, and cardiac phenotypes in laminopathies, diabetic cardiomyopathy, and ischemia-reperfusion injury [16-18]. Several cellular responses related to stress and aging are downstream of FoxO $[85,86]$. The expression of TMEM135 is connected to several stress-induced signaling pathways, including the p38 pathway [87]. Upstream of FoxO, the p38 signal transduction pathway mediates FoxO translocation to the nucleus [87]. The c-Jun N-terminal kinase is also a positive regulator of FoxO that mediates FoxO translocation to the nucleus $[85,86]$. Interestingly, c-Jun is a $\mathrm{Ca}^{2+}$-dependent kinase along with ATF4, an isoform of CREB. Fusakio et al. showed that ATF4 enhances the transcription of genes involved in oxidative stress, ER stress, and mitochondrial stress [88]. Because TMEM135 appears critical for FoxO regulation [11], it might have clinical relevance for aging and heart-failure biology, beyond fatty-acid beta-oxidation defects.

Despite the lack of a current structure for TMEM135, several proteins have experimental and predicted interactions with TMEM135 that have roles in calcium signaling, including Sphingomyelin phosphodiesterase (SMPD3) $[89,90]$. Detected experimentally by affinity chromatography assay $[89,90]$, TMEM135 and SMPD3 share an association (https:/ / string-db.org/network/9606.ENSP00000306344, accessed 1 July 2021). It is well understood that sphingolipids are integral parts of lipid membranes [91]. More importantly, sphingolipids can activate or inhibit channels and modulate calcium signaling [92]. Interestingly, the function of SMPD3 is to hydrolyze sphingomyelin to form ceramide and phosphocholine [93-95]. SMPD3 has a crystallized structure (5UVG) that has two calcium ion ligands $[96,97]$. Given the localization TMEM135 has with lipid droplets and the experimental evidence of interaction and shared homology with SMPD3, we postulate that TMEM135 has a role in altering $\mathrm{Ca}^{2+}$ dynamics.

\section{General Characteristics and Profiling of TMEM135 in Human Diseases}

Many TMEM proteins contribute to oncogenesis, including TMEM135 [70,97]. In humans, TMEM135 was identified as an apoptosis-regulating protein in BRCA1-mutant estrogen receptor-positive breast cancer $[27,55,62,70]$. Natrajan et al. performed a sequencing analysis of independent hereditary $B R C A 1$ and non-BRCA1 breast cancers cases and identified TMEM135 as a potential driver of breast cancer [98]. TMEM135 mutations were also identified in melanoma patients and in recurrent gene fusions associated with several other cancers $[99,100]$.

TMEM135 is highly expressed in brain tissue. A study by Franic et al. suggested an association between TMEM135, learning, and intelligence [101]. In mice, the pathogenic FUN25 mutation in TMEM135 was associated with age-dependent pathologies, including accelerated retinal aging reminiscent of human macular degeneration; however, mutations in human TMEM135 have not been reported in macular degeneration patients [12].

Human interactome studies looking at networks of protein-protein interactions suggest that TMEM135 interacts with proteins involved in lipid synthesis, cholesterol-binding, cholesterol transport, membrane rafting, and $\mathrm{Ca}^{2+}$ modulation, including sphingomyelin phosphodiesterase 3 (SMPD3), which has a critical role in ceramide synthesis [102-104]. TMEM135 was also found to be differentially expressed (with a high degree of ethnic difference) in subcutaneous adipose tissue between insulin-resistant and insulin-sensitive individuals when matched for body mass index [57].

Genome-wide association studies revealed that TMEM135 is involved in bone density maintenance and osteoporosis [64]. Furthermore, large and rare copy-number variations in TMEM135 were associated with moderate to extreme obesity [58]. TMEM135 is also differentially expressed in peripheral blood mononuclear cells of patients after treatment with a high-dose statin, a cholesterol-lowering medication, in the YELLOW II Study, in- 
dicating a potential role in inflammation and/or cholesterol flux capacity [37]. Chu et al., demonstrated that when TMEM135 was knocked down, the plasma membrane cholesterol levels were significantly reduced, suggesting that TMEM135 has a unique and integral role in lysosome-peroxisome membrane contacts [66]. Further studies reported that perturbed intracellular cholesterol distribution imposed by lysosomal cholesterol accumulation during TMEM135 depletion, is closely associated with impaired ciliogenesis [69]. TMEM135 depletion prevents ciliary vesicle elongation, a characteristic of impaired Rab8 function [69]. In addition, TMEM is also involved in chemically induced hepatic steatosis (non-alcoholic fatty liver disease) [105] and hypertrophic cardiomyopathy [106]. Forced overexpression TMEM135 in mouse hearts led to a form of cardiomyopathy characterized by hypertrophy, increased collagen deposits, and premature cardiac aging [20].

\section{Perspective}

The role of TMEM135 in mitochondrial dynamics has implications for adipogenesis, mitochondrial function, and fat storage. Previous reports suggest a critical link between TMEM135 and aging; however, there is still no definitive insight into the role of TMEM135 in aging outside of phenotypic observations linked to polymorphisms in the TMEM135 gene [12]. A TMEM135 crystal structure could delineate the exact position of TMEM135 in mitochondrial metabolism and dynamics, as well as the cellular physiology and biophysical characteristics of the protein. Using I-TASSER (Iterative Threading ASSEmbly Refinement) software (version 5.1) [71,72,107], we have determined potential ligands, including oleic acid, chlorophyll, and derivatives of glucose, to interact with TMEM135 (Figure 5).

Due to the lack of characterization of the electrical and biophysical properties of TMEM135, it will be helpful to use biophysical techniques such as patch clamping to determine which agonist(s) activates TMEM135. Additionally, a better understanding of the activation of TMEM135, e.g., activation by mechanical force, would prove helpful. Interestingly, it has been well established that ion channels can change the cell membrane potential $[5,108,109]$. Therefore, further investigation is needed to understand how TMEM135 can change the membrane potential. One way to experimentally test this is by overexpressing TMEM135 in a well-characterized cell line such as HEK293 or CHO cells and assessing biophysical changes.

Further research into the precise subcellular localization of TMEM135 would be beneficial for understanding the functions of TMEM135. Additionally, the activity-regulating ligands and kinases of TMEM135 have yet to be identified. TMEM135 may serve as a target for future anti-aging therapeutics, but further study is required. Creating a conditional lossof-function mouse system would be beneficial to understanding the effects of TMEM135 ablation and overexpression in the tissue of interest. Overall, TMEM135 has been implicated to be a novel regulator of mitochondrial dynamics and cell physiology $[6,37,38,45-50]$; thereby, making TMEM135 a critical piece in understanding health and disease. 


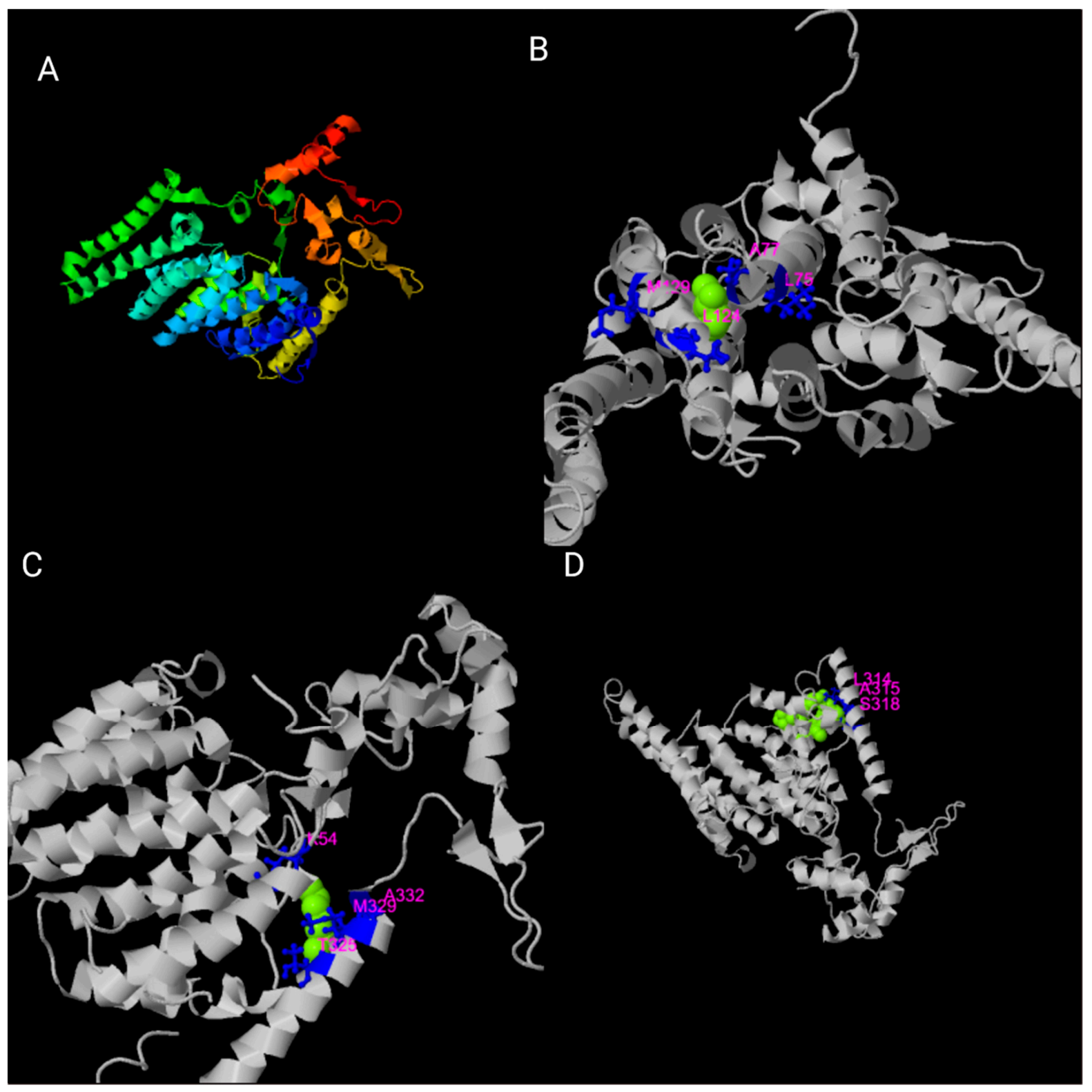

Figure 5. Predicted ligands for TMEM135 using I-TASSER software [71,72,107]. (A) The different colors represent the different alpha helixes. (B-D) I-TASSER (version 5.1) software provides biological annotations of the target ligand by $\mathrm{COACH}$ based on the I-TASSER structure prediction, represented by the magenta-colored amino acid residues. Figure created with BioRender.com (accessed on 15 June 2021).

Author Contributions: Conceptualization, A.H.J. and V.E.; methodology, H.K.B., T.A.R., A.H.J.; software, H.K.B., T.A.R.; validation, H.K.B., G.V.C., A.H.J., and V.E.; formal analysis, H.K.B., T.A.R.; investigation, H.K.B., G.V.C., A.H.J., V.E.; resources, A.H.J., and V.E.; data curation, H.K.B., T.A.R., G.V.C.; A.H.J., and V.E; writing-original draft preparation, H.K.B.; A.H.J., and V.E.; writing-review and editing, H.K.B., A.H.J.; visualization, H.K.B.; supervision, G.V.C.,; project administration, H.K.B., A.H.J., and V.E; funding acquisition, A.H.J. All authors have read and agreed to the published version of the manuscript.

Funding: This research was funded by Burroughs Wellcome Fund Award Career Awards at the Scientific Interface (CASI), UNCF/BMS EE Just Faculty Fund, the Ford Foundation, and NIH SRP subaward to \#5R25HL106365-12 from the NIH PRIDE Program.

Acknowledgments: We would like to thank Zer Vue and Edgar Garza Lopez of Vanderbilt University for considerable edits, constructive feedback on the perspective section of the review, and for insight on how to use the I-TASSER software. 
Conflicts of Interest: The authors declare no conflict of interest.

\section{References}

1. Marx, S.; Maso, T.D.; Chen, J.-W.; Bury, M.; Wouters, J.; Michiels, C.; Le Calvé, B. Transmembrane (TMEM) protein family members: Poorly characterized even if essential for the metastatic process. Semin. Cancer Biol. 2020, 60, 96-106. [CrossRef]

2. Fuller, C.M. Time for TMEM? J. Physiol. 2012, 590, 5931-5932. [CrossRef]

3. Vinothkumar, K.R.; Henderson, R. Structures of membrane proteins. Q. Rev. Biophys. 2010, 43, 65-158. [CrossRef]

4. Von Heijne, G. Membrane-protein topology. Nat. Rev. Mol. Cell Biol. 2006, 7, 909-918. [CrossRef]

5. Alberts, B. (Ed.) Molecular Biology of the Cell, 5th ed.; Alberts, B. (Ed.) Garland Science: New York, NY, USA, 2008; ISBN 978-0-8153-4105-5.

6. Ruiz, M.D.L.; Kraus, R.L. Voltage-Gated Sodium Channels: Structure, Function, Pharmacology, and Clinical Indications. J. Med. Chem. 2015, 58, 7093-7118. [CrossRef]

7. Abbott, G.W. KCNQs: Ligand- and Voltage-Gated Potassium Channels. Front. Physiol. 2020, 11, 583. [CrossRef] [PubMed]

8. Bouza, A.A.; Isom, L.L. Voltage-Gated Sodium Channel $\beta$ Subunits and Their Related Diseases. In Handbook of Experimental Pharmacology; Springer Science and Business Media LLC: New York, NY, USA, 2017; Volume 246, pp. $423-450$.

9. Kaplan, D.I.; Isom, L.L.; Petrou, S. Role of Sodium Channels in Epilepsy. Cold Spring Harb. Perspect. Med. 2016, 6, a022814. [CrossRef]

10. Kruger, L.C.; Isom, L.L. Voltage-Gated Na+Channels: Not Just for Conduction. Cold Spring Harb. Perspect. Biol. 2016, 8, a029264. [CrossRef]

11. Exil, V.J.; Avila, D.S.; Benedetto, A.; Exil, E.A.; Adams, M.R.; Au, C.; Aschner, M. Stressed-Induced TMEM135 Protein Is Part of a Conserved Genetic Network Involved in Fat Storage and Longevity Regulation in C. elegans. PLoS ONE 2010, 5, e14228. [CrossRef]

12. Lee, W.-H.; Higuchi, H.; Ikeda, S.; Macke, E.L.; Takimoto, T.; Pattnaik, B.; Liu, C.; Chu, L.-F.; Siepka, S.M.; Krentz, K.J.; et al. Mouse Tmem135 mutation reveals a mechanism involving mitochondrial dynamics that leads to age-dependent retinal pathologies. eLife 2016, 5. [CrossRef]

13. Zaucha, J.; Heinzinger, M.; Kulandaisamy, A.; Kataka, E.; Salvádor Óscar, L.; Popov, P.; Rost, B.; Gromiha, M.M.; Zhorov, B.S.; Frishman, D. Mutations in transmembrane proteins: Diseases, evolutionary insights, prediction and comparison with globular proteins. Briefings Bioinform. 2021, 22. [CrossRef]

14. Sánchez-Caballero, L.; Elurbe, D.M.; Baertling, F.; Guerrero-Castillo, S.; van der Brand, M.; van Strien, J.; van Dam, T.J.; Rodenburg, R.; Brandt, U.; Huynen, M.A.; et al. TMEM70 functions in the assembly of complexes I and V. Biochim. Biophys. Acta 2020, 1861, 148202. [CrossRef]

15. Kovalčíková, J.; Vrbacký, M.; Pecina, P.; Tauchmannová, K.; Nůsková, H.; Kaplanová, V.; Brázdová, A.; Alán, L.; Eliáš, J.; Čunátová, K.; et al. TMEM70 facilitates biogenesis of mammalian ATP synthase by promoting subunit c incorporation into the rotor structure of the enzyme. FASEB J. 2019, 33, 14103-14117. [CrossRef] [PubMed]

16. Bahri, H.; Buratto, J.; Rojo, M.; Dompierre, J.P.; Salin, B.; Blancard, C.; Cuvellier, S.; Rose, M.; Elgaaied, A.B.A.; Tetaud, E.; et al. TMEM70 forms oligomeric scaffolds within mitochondrial cristae promoting in situ assembly of mammalian ATP synthase proton channel. Biochim. Biophys. Acta (BBA)-Bioenerg. 2021, 1868, 118942. [CrossRef]

17. Vrbacky, M.; Kovalčíková, J.; Chawengsaksophak, K.; Beck, I.M.; Mráček, T.; Nůsková, H.; Sedmera, D.; Papoušek, F.; Kolar, F.; Sobol, M.; et al. Knockout of Tmem70 alters biogenesis of ATP synthase and leads to embryonal lethality in mice. Hum. Mol. Genet. 2016, 25, 4674-4685. [CrossRef] [PubMed]

18. Kratochvílová, H.; Hejzlarová, K.; Vrbacky, M.; Mráček, T.; Karbanová, V.; Tesarova, M.; Gombitová, A.; Cmarko, D.; Wittig, I.; Zeman, J.; et al. Mitochondrial membrane assembly of TMEM70 protein. Mitochondrion 2014, 15, 1-9. [CrossRef] [PubMed]

19. Magner, M.; Dvorakova, V.; Tesarova, M.; Mazurova, S.; Hansikova, H.; Zahorec, M.; Brennerova, K.; Bzduch, V.; Spiegel, R.; Horovitz, Y.; et al. TMEM70 deficiency: Long-term outcome of 48 patients. J. Inherit. Metab. Dis. 2014, 38, 417-426. [CrossRef]

20. Carroll, J.; He, J.; Ding, S.; Fearnley, I.M.; Walker, J.E. TMEM70 and TMEM242 help to assemble the rotor ring of human ATP synthase and interact with assembly factors for complex I. Proc. Natl. Acad. Sci. USA 2021, 118. [CrossRef] [PubMed]

21. Mathur, A.; Sims, H.F.; Gopalakrishnan, D.; Gibson, B.; Rinaldo, P.; Vockley, J.; Hug, G.; Strauss, A.W. Molecular Heterogeneity in Very-Long-Chain Acyl-CoA Dehydrogenase Deficiency Causing Pediatric Cardiomyopathy and Sudden Death. Circulation 1999, 99, 1337-1343. [CrossRef]

22. Aoyama, T.; Uchida, Y.; Kelley, R.; Marble, M.; Hofman, K.; Tonsgard, J.; Rhead, W.; Hashimoto, T. A Novel Disease with Deficiency of Mitochondrial Very-Long-Chain Acyl-CoA Dehydrogenase. Biochem. Biophys. Res. Commun. 1993, 191, 1369-1372. [CrossRef]

23. Aoyama, T.; Souri, M.; Ueno, I.; Kamijo, T.; Yamaguchi, S.; Rhead, W.J.; Tanaka, K.; Hashimoto, T. Cloning of human very-longchain acyl-coenzyme A dehydrogenase and molecular characterization of its deficiency in two patients. Am. J. Hum. Genet. 1995, 57, 273-283. [PubMed]

24. Souri, M.; Aoyama, T.; Orii, K.; Yamaguchi, S.; Hashimoto, T. Mutation analysis of very-long-chain acyl-coenzyme A dehydrogenase (VLCAD) deficiency: Identification and characterization of mutant VLCAD cDNAs from four patients. Am. J. Hum. Genet. 1996, 58, 97-106. [PubMed] 
25. Bertrand, C.; Largillière, C.; Zabot, M.T.; Mathieu, M.; Vianey-Saban, C. Very long chain acyl-CoA dehydrogenase deficiency: Identification of a new inborn error of mitochondrial fatty acid oxidation in fibroblasts. Biochim. Biophys. Acta (BBA)-Mol. Basis Dis. 1993, 1180, 327-329. [CrossRef]

26. Exil, V.J.; Roberts, R.L.; Sims, H.; McLaughlin, J.E.; Malkin, R.A.; Gardner, C.D.; Ni, G.; Rottman, J.N.; Strauss, A.W. Very-LongChain Acyl-Coenzyme A Dehydrogenase Deficiency in Mice. Circ. Res. 2003, 93, 448-455. [CrossRef] [PubMed]

27. Scheideler, M.; Elabd, C.; Zaragosi, L.-E.; Chiellini, C.; Hackl, H.; Sanchez-Cabo, F.; Yadav, S.; Duszka, K.; Friedl, G.; Papak, C.; et al. Comparative transcriptomics of human multipotent stem cells during adipogenesis and osteoblastogenesis. BMC Genom. 2008, 9, 340. [CrossRef] [PubMed]

28. Antebi, A.; Culotti, J.; Hedgecock, E. daf-12 regulates developmental age and the dauer alternative in C. elegans. Development 1998, 125, 1191-1205. [CrossRef] [PubMed]

29. Gottlieb, S.; Ruvkun, G. daf-2, daf-16 and daf-23: Genetically interacting genes controlling Dauer formation in C. elegans. Genetics 1994, 137, 107-120. [CrossRef] [PubMed]

30. Lin, K.; Dorman, J.B.; Rodan, A.; Kenyon, C. daf-16: An HNF-3/forkhead Family Member That Can Function to Double the Life-Span of C. elegans. Science 1997, 278, 1319-1322. [CrossRef]

31. Ogg, S.; Paradis, S.; Gottlieb, S.; Patterson, G.I.; Lee, L.; Tissenbaum, H.A.; Ruvkun, G. The Fork head transcription factor DAF-16 transduces insulin-like metabolic and longevity signals in C. elegans. Nat. Cell Biol. 1997, 389, 994-999. [CrossRef]

32. Paradis, S.; Ruvkun, G. C. elegans Akt/PKB transduces insulin receptor-like signals from AGE-1 PI3 kinase to the DAF-16 transcription factor. Genes Dev. 1998, 12, 2488-2498. [CrossRef]

33. Lee, S.S.; Kennedy, S.; Tolonen, A.; Ruvkun, G. DAF-16 Target Genes That Control C. elegans Life-Span and Metabolism. Science 2003, 300, 644-647. [CrossRef]

34. McElwee, J.; Bubb, K.; Thomas, J.H. Transcriptional outputs of the C. elegans forkhead protein DAF-16. Aging Cell 2003, 2, 111-121. [CrossRef]

35. Kimura, K.; Tissenbaum, H.A.; Liu, Y.; Ruvkun, G. daf-2, an Insulin Receptor-Like Gene That Regulates Longevity and Diapause in C. elegans. Science 1997, 277, 942-946. [CrossRef] [PubMed]

36. Madeira, F.; Park, Y.M.; Lee, J.; Buso, N.; Gur, T.; Madhusoodanan, N.; Basutkar, P.; Tivey, A.R.N.; Potter, S.C.; Finn, R.D.; et al. The EMBL-EBI search and sequence analysis tools APIs in 2019. Nucleic Acids Res. 2019, 47, W636-W641. [CrossRef] [PubMed]

37. Rosca, M.; Hoppel, C.L. Mitochondrial dysfunction in heart failure. Hear. Fail. Rev. 2013, 18, 607-622. [CrossRef]

38. Liesa, M.; Palacín, M.; Zorzano, A. Mitochondrial Dynamics in Mammalian Health and Disease. Physiol. Rev. 2009, 89, 799-845. [CrossRef]

39. Chen, H.; Chan, D.C. Physiological functions of mitochondrial fusion. Ann. N. Y. Acad. Sci. 2010, 1201, 21-25. [CrossRef] [PubMed]

40. Naon, D.; Zaninello, M.; Giacomello, M.; Varanita, T.; Grespi, F.; Lakshminaranayan, S.; Serafini, A.; Semenzato, M.; Herkenne, S.; Hernández-Alvarez, M.I.; et al. Critical reappraisal confirms that Mitofusin 2 is an endoplasmic reticulum-mitochondria tether. Proc. Natl. Acad. Sci. USA 2016, 113, 11249-11254. [CrossRef]

41. Muñoz, J.P.; Ivanova, S.; Wandelmer, J.S.; Martínez-Cristóbal, P.; Noguera, M.; Sancho, A.; Díaz-Ramos, A.; Hernández-Alvarez, M.I.; Sebastián, D.; Mauvezin, C.; et al. Mfn2 modulates the UPR and mitochondrial function via repression of PERK. EMBO J. 2013, 32, 2348-2361. [CrossRef]

42. Sebastián, D.; Sorianello, E.; Segalés, J.; Irazoki, A.; Ruiz-Bonilla, V.; Sala, D.; Planet, E.; Berenguer-Llergo, A.; Muñoz, J.P.; Sánchez-Feutrie, M.; et al. Mfn2 deficiency links age-related sarcopenia and impaired autophagy to activation of an adaptive mitophagy pathway. EMBO J. 2016, 35, 1677-1693. [CrossRef]

43. Favaro, G.; Romanello, V.; Varanita, T.; Desbats, M.A.; Morbidoni, V.; Tezze, C.; Albiero, M.; Canato, M.; Gherardi, G.; De Stefani, D.; et al. DRP1-mediated mitochondrial shape controls calcium homeostasis and muscle mass. Nat. Commun. 2019, $10,1-17$. [CrossRef] [PubMed]

44. Dulac, M.; Leduc-Gaudet, J.; Reynaud, O.; Ayoub, M.; Guérin, A.; Finkelchtein, M.; Na Hussain, S.; Gouspillou, G. Drp1 knockdown induces severe muscle atrophy and remodelling, mitochondrial dysfunction, autophagy impairment and denervation. J. Physiol. 2020, 598, 3691-3710. [CrossRef] [PubMed]

45. Scott, I.; Youle, R.J. Mitochondrial fission and fusion. Essays Biochem. 2010, 47, 85-98. [CrossRef] [PubMed]

46. Lee, W.-H.; Bhute, V.J.; Higuchi, H.; Ikeda, S.; Palecek, S.P.; Ikeda, A. Metabolic alterations caused by the mutation and overexpression of the Tmem135 gene. Exp. Biol. Med. 2020, 245, 1571-1583. [CrossRef]

47. Pereira, R.O.; Tadinada, S.M.; Zasadny, F.M.; Oliveira, K.J.; Pires, K.M.P.; Olvera, A.; Jeffers, J.; Souvenir, R.; McGlauflin, R.; Seei, A.; et al. OPA 1 deficiency promotes secretion of FGF 21 from muscle that prevents obesity and insulin resistance. EMBO J. 2017, 36, 2126-2145. [CrossRef]

48. Ren, L.; Chen, X.; Chen, X.; Li, J.; Cheng, B.; Xia, J. Mitochondrial Dynamics: Fission and Fusion in Fate Determination of Mesenchymal Stem Cells. Front. Cell Dev. Biol. 2020, 8, 580070. [CrossRef]

49. Cipolat, S.; De Brito, O.M.; Zilio, B.D.; Scorrano, L. OPA1 requires mitofusin 1 to promote mitochondrial fusion. Proc. Natl. Acad. Sci. USA 2004, 101, 15927-15932. [CrossRef]

50. Varanita, T.; Soriano, M.E.; Romanello, V.; Zaglia, T.; Quintana-Cabrera, R.; Semenzato, M.; Menabò, R.; Costa, V.; Civiletto, G.; Pesce, P.; et al. The Opa1-Dependent Mitochondrial Cristae Remodeling Pathway Controls Atrophic, Apoptotic, and Ischemic Tissue Damage. Cell Metab. 2015, 21, 834-844. [CrossRef] [PubMed] 
51. Dietrich, M.O.; Liu, Z.-W.; Horvath, T.L. Mitochondrial Dynamics Controlled by Mitofusins Regulate Agrp Neuronal Activity and Diet-Induced Obesity. Cell 2013, 155, 188-199. [CrossRef] [PubMed]

52. Lewis, S.; Takimoto, T.; Mehrvar, S.; Higuchi, H.; Doebley, A.-L.; Stokes, G.; Sheibani, N.; Ikeda, S.; Ranji, M.; Ikeda, A. The effect of Tmem135 overexpression on the mouse heart. PLoS ONE 2018, 13, e0201986. [CrossRef]

53. Faust, J.; Verma, A.; Peng, C.; McNew, J.A. An Inventory of Peroxisomal Proteins and Pathways in Drosophila melanogaster. Traffic 2012, 13, 1378-1392. [CrossRef]

54. Cipolla, C.M.; Lodhi, I.J. Peroxisomal Dysfunction in Age-Related Diseases. Trends Endocrinol. Metab. 2017, 28, 297-308. [CrossRef] [PubMed]

55. Renquist, B.J.; Madanayake, T.W.; Hennebold, J.D.; Ghimire, S.; Geisler, C.E.; Xu, Y.; Bogan, R.L. TMEM135 Is an LXR-Inducible Regulator of Peroxisomal Metabolism. Cell Biology 2018, 334979. [CrossRef]

56. Teraoka, S.N.; Bernstein, J.L.; Reiner, A.S.; Haile, R.W.; Bernstein, L.; Lynch, C.F.; Malone, K.E.; Stovall, M.; Capanu, M.; Liang, X.; et al. Single nucleotide polymorphisms associated with risk for contralateral breast cancer in the Women's Environment, Cancer, and Radiation Epidemiology (WECARE) Study. Breast Cancer Res. 2011, 13, R114. [CrossRef]

57. Elbein, S.C.; Kern, P.A.; Rasouli, N.; Yao-Borengasser, A.; Sharma, N.K.; Das, S.K. Global Gene Expression Profiles of Subcutaneous Adipose and Muscle From Glucose-Tolerant, Insulin-Sensitive, and Insulin-Resistant Individuals Matched for BMI. Diabetes 2011, 60, 1019-1029. [CrossRef] [PubMed]

58. Wang, K.; Li, W.-D.; Glessner, J.; Grant, S.; Hakonarson, H.; Price, R.A. Large Copy-Number Variations Are Enriched in Cases With Moderate to Extreme Obesity. Diabetes 2010, 59, 2690-2694. [CrossRef]

59. Rieusset, J. The role of endoplasmic reticulum-mitochondria contact sites in the control of glucose homeostasis: An update. Cell Death Dis. 2018, 9, 388. [CrossRef] [PubMed]

60. Tubbs, E.; Chanon, S.; Robert, M.; Bendridi, N.; Bidaux, G.; Chauvin, M.-A.; Ji-Cao, J.; Durand, C.; Gauvrit-Ramette, D.; Vidal, H.; et al. Disruption of Mitochondria-Associated Endoplasmic Reticulum Membrane (MAM) Integrity Contributes to Muscle Insulin Resistance in Mice and Humans. Diabetes 2018, 67, 636-650. [CrossRef]

61. Tubbs, E.; Theurey, P.; Vial, G.; Bendridi, N.; Bravard, A.; Chauvin, M.-A.; Ji-Cao, J.; Zoulim, F.; Bartosch, B.; Ovize, M.; et al. Mitochondria-Associated Endoplasmic Reticulum Membrane (MAM) Integrity Is Required for Insulin Signaling and Is Implicated in Hepatic Insulin Resistance. Diabetes 2014, 63, 3279-3294. [CrossRef] [PubMed]

62. Kuzmicic, J.; del Campo, A.; López-Crisosto, C.; Morales, P.E.; Pennanen, C.; Bravo-Sagua, R.; Hechenleitner, J.; Zepeda, R.; Castro, P.F.; Verdejo, H.E.; et al. Dinámica mitocondrial: Un potencial nuevo blanco terapéutico para la insuficiencia cardiaca. Rev. Española Cardiol. 2011, 64, 916-923. [CrossRef] [PubMed]

63. Correa-Rodríguez, M.; Viatte, S.; Massey, J.; Schmidt-RioValle, J.; Rueda-Medina, B.; Orozco, G. Analysis of SNP-SNP interactions and bone quantitative ultrasound parameter in early adulthood. BMC Med Genet. 2017, 18, 107. [CrossRef]

64. Mullin, B.H.; Zhao, J.H.; Brown, S.J.; Perry, J.R.; Luan, J.; Zheng, H.-F.; Langenberg, C.; Dudbridge, F.; Scott, R.; Wareham, N.J.; et al. Genome-wide association study meta-analysis for quantitative ultrasound parameters of bone identifies five novel loci for broadband ultrasound attenuation. Hum. Mol. Genet. 2017, 26, 2791-2802. [CrossRef]

65. Breckenridge, D.G.; Stojanovic, M.; Marcellus, R.C.; Shore, G.C. Caspase cleavage product of BAP31 induces mitochondrial fission through endoplasmic reticulum calcium signals, enhancing cytochrome c release to the cytosol. J. Cell Biol. 2003, 160, 1115-1127. [CrossRef]

66. Chu, B.-B.; Liao, Y.-C.; Qi, W.; Xie, C.; Du, X.; Wang, J.; Yang, H.; Miao, H.-H.; Li, B.-L.; Song, B.-L. Cholesterol Transport through Lysosome-Peroxisome Membrane Contacts. Cell 2015, 161, 291-306. [CrossRef] [PubMed]

67. Uhlén, M.; Fagerberg, L.; Hallström, B.M.; Lindskog, C.; Oksvold, P.; Mardinoglu, A.; Sivertsson, Å.; Kampf, C.; Sjöstedt, E.; Asplund, A.; et al. Tissue-based map of the human proteome. Science 2015, 347, 1260419. [CrossRef] [PubMed]

68. Silva, B.S.; DiGiovanni, L.; Kumar, R.; Carmichael, R.E.; Kim, P.K.; Schrader, M. Maintaining social contacts: The physiological relevance of organelle interactions. Biochim. Biophys. Acta (BBA) Bioenerg. 2020, 1867, 118800. [CrossRef] [PubMed]

69. Maharjan, Y.; Lee, J.N.; Kwak, S.A.; Dutta, R.K.; Park, C.; Choe, S.; Park, R. TMEM135 regulates primary ciliogenesis through modulation of intracellular cholesterol distribution. EMBO Rep. 2020, 21, e48901. [CrossRef] [PubMed]

70. Schmit, K.; Michiels, C. TMEM Proteins in Cancer: A Review. Front. Pharmacol. 2018, 9, 1345. [CrossRef] [PubMed]

71. Roy, A.; Kucukural, A.; Zhang, Y. I-TASSER: A unified platform for automated protein structure and function prediction. Nat. Protoc. 2010, 5, 725-738. [CrossRef]

72. Yang, J.; Zhang, Y. I-TASSER server: New development for protein structure and function predictions. Nucleic Acids Res. 2015, 43, W174-W181. [CrossRef]

73. Hittelman, K.J.; Fairhurst, A.S.; Smith, R.E. Calcium accumulation as a parameter of energy metabolism in mitochondria of brown adipose tissue. Proc. Natl. Acad. Sci. USA 1967, 58, 697-702. [CrossRef]

74. Golic, I.; Veličković, K.; Markelic, M.; Stancic, A.; Jankovic, A.; Vucetic, M.; Otasevic, V.; Buzadzic, B.; Korac, B.; Korać, A. Calcium-induced alteration of mitochondrial morphology and mitochondrial-endoplasmic reticulum contacts in rat brown adipocytes. Eur. J. Histochem. 2014, 58, 2377. [CrossRef]

75. Otera, H.; Ishihara, N.; Mihara, K. New insights into the function and regulation of mitochondrial fission. Biochim. Biophys. Acta (BBA)-Bioenerg. 2013, 1833, 1256-1268. [CrossRef]

76. Giacomello, M.; Pellegrini, L. The coming of age of the mitochondria-ER contact: A matter of thickness. Cell Death Differ. 2016, 23, 1417-1427. [CrossRef] 
77. Vance, J.E. MAM (mitochondria-associated membranes) in mammalian cells: Lipids and beyond. Biochim. Biophys. Acta (BBA)-Mol. Cell Biol. Lipids 2014, 1841, 595-609. [CrossRef] [PubMed]

78. Rowland, A.A.; Voeltz, G.K. Endoplasmic reticulum-mitochondria contacts: Function of the junction. Nat. Rev. Mol. Cell Biol. 2012, 13, 607-615. [CrossRef] [PubMed]

79. Dewenter, M.; Von Der Lieth, A.; Katus, H.A.; Backs, J. Calcium Signaling and Transcriptional Regulation in Cardiomyocytes. Circ. Res. 2017, 121, 1000-1020. [CrossRef] [PubMed]

80. West, A.E.; Chen, W.G.; Dalva, M.B.; Dolmetsch, R.E.; Kornhauser, J.M.; Shaywitz, A.J.; Takasu, M.A.; Tao, X.; Greenberg, M.E. Calcium regulation of neuronal gene expression. Proc. Natl. Acad. Sci. USA 2001, 98, 11024-11031. [CrossRef] [PubMed]

81. Shambharkar, P.B.; Bittinger, M.; Latario, B.; Xiong, Z.; Bandyopadhyay, S.; Davis, V.; Lin, V.; Yang, Y.; Valdez, R.; Labow, M.A. TMEM203 Is a Novel Regulator of Intracellular Calcium Homeostasis and Is Required for Spermatogenesis. PLoS ONE 2015, 10, e0127480. [CrossRef] [PubMed]

82. Markin, A.; Khotina, V.; Zabudskaya, X.; Bogatyreva, A.; Starodubova, A.; Ivanova, E.; Nikiforov, N.; Orekhov, A. Disturbance of Mitochondrial Dynamics and Mitochondrial Therapies in Atherosclerosis. Life 2021, 11, 165. [CrossRef] [PubMed]

83. Landowski, M.; Grindel, S.; Shahi, P.K.; Johnson, A.; Western, D.; Race, A.; Shi, F.; Benson, J.; Gao, M.; Santoirre, E.; et al. Modulation of Tmem135 Leads to Retinal Pigmented Epithelium Pathologies in Mice. Investig. Opthalmology Vis. Sci. 2020, 61, 16. [CrossRef]

84. Spurthi, K.M.; Sarikhani, M.; Mishra, S.; Desingu, P.A.; Yadav, S.; Rao, S.; Maity, S.; Tamta, A.K.; Kumar, S.; Majumdar, S.; et al. Toll-like receptor 2 deficiency hyperactivates the FoxO1 transcription factor and induces aging-associated cardiac dysfunction in mice. J. Biol. Chem. 2018, 293, 13073-13089. [CrossRef] [PubMed]

85. Jia, K.; Chen, D.; Riddle, D.L. The TOR pathway interacts with the insulin signaling pathway to regulate C. elegans larval development, metabolism and life span. Development 2004, 131, 3897-3906. [CrossRef]

86. Vellai, T.; Takacs-Vellai, K.; Zhang, Y.; Kovacs, A.L.; Orosz, L.; Müller, F. Influence of TOR kinase on lifespan in C. elegans. Nat. Cell Biol. 2003, 426, 620. [CrossRef] [PubMed]

87. Kondo, M.; Yanase, S.; Ishii, T.; Hartman, P.S.; Matsumoto, K.; Ishii, N. The p38 signal transduction pathway participates in the oxidative stress-mediated translocation of DAF-16 to C. elegans nuclei. Mech. Ageing Dev. 2005, 126, 642-647. [CrossRef] [PubMed]

88. Fusakio, M.E.; Willy, J.A.; Wang, Y.; Mirek, E.T.; Al Baghdadi, R.J.T.; Adams, C.; Anthony, T.G.; Wek, R.C. Transcription factor ATF4 directs basal and stress-induced gene expression in the unfolded protein response and cholesterol metabolism in the liver. Mol. Biol. Cell 2016, 27, 1536-1551. [CrossRef] [PubMed]

89. Szklarczyk, D.; Gable, A.L.; Lyon, D.; Junge, A.; Wyder, S.; Huerta-Cepas, J.; Simonovic, M.; Doncheva, N.T.; Morris, J.H.; Bork, P.; et al. STRING v11: Protein-protein association networks with increased coverage, supporting functional discovery in genome-wide experimental datasets. Nucleic Acids Res. 2019, 47, D607-D613. [CrossRef] [PubMed]

90. Stark, C.; Breitkreutz, B.J.; Reguly, T.; Boucher, L.; Breitkreutz, A.; Tyers, M. BioGRID: A general repository for interaction datasets. Nucleic Acids Res. 2006, 34, D535-D539. [CrossRef]

91. Khavandgar, Z.; Murshed, M. Sphingolipid metabolism and its role in the skeletal tissues. Cell. Mol. Life Sci. 2014, 72, 959-969. [CrossRef]

92. Pulli, I.; Asghar, M.Y.; Kemppainen, K.; Törnquist, K. Sphingolipid-mediated calcium signaling and its pathological effects. Biochim. Biophys. Acta (BBA)—Bioenerg. 2018, 1865, 1668-1677. [CrossRef]

93. Marchesini, N.; Osta, W.; Bielawski, J.; Luberto, C.; Obeid, L.M.; Hannun, Y.A. Role for Mammalian Neutral Sphingomyelinase 2 in Confluence-induced Growth Arrest of MCF7 Cells. J. Biol. Chem. 2004, 279, 25101-25111. [CrossRef]

94. Hofmann, K.; Tomiuk, S.; Wolff, G.; Stoffel, W. Cloning and characterization of the mammalian brain-specific, Mg2+-dependent neutral sphingomyelinase. Proc. Natl. Acad. Sci. USA 2000, 97, 5895-5900. [CrossRef] [PubMed]

95. Miura, Y.; Gotoh, E.; Nara, F.; Nishijima, M.; Hanada, K. Hydrolysis of sphingosylphosphocholine by neutral sphingomyelinases. FEBS Lett. 2004, 557, 288-292. [CrossRef]

96. Sehnal, D.; Bittrich, S.; Deshpande, M.; Svobodová, R.; Berka, K.; Bazgier, V.; Velankar, S.; Burley, S.K.; Koča, J.; Rose, A.S. $\mathrm{Mol}^{*}$ Viewer: Modern web app for 3D visualization and analysis of large biomolecular structures. Nucleic Acids Res. 2021, 49, W431-W437. [CrossRef] [PubMed]

97. Airola, M.; Shanbhogue, P.; Shamseddine, A.A.; Guja, K.E.; Senkal, C.E.; Maini, R.; Bartke, N.; Wu, B.X.; Obeid, L.M.; Garcia-Diaz, M.; et al. Structure of human nSMase2 reveals an interdomain allosteric activation mechanism for ceramide generation. Proc. Natl. Acad. Sci. USA 2017, 114, E5549-E5558. [CrossRef]

98. Natrajan, R.; Mackay, A.; Lambros, M.B.; Weigelt, B.; Wilkerson, P.M.; Manie, E.; Grigoriadis, A.; A’Hern, R.; Van Der Groep, P.; Kozarewa, I.; et al. A whole-genome massively parallel sequencing analysis of BRCA1 mutant oestrogen receptor-negative and -positive breast cancers. J. Pathol. 2012, 227, 29-41. [CrossRef]

99. Li, J.; Zhong, H.-Y.; Zhang, Y.; Xiao, L.; Bai, L.-H.; Liu, S.-F.; Zhou, G.-B.; Zhang, G.-S. GTF2I-RARAis a novel fusion transcript in a $\mathrm{t}(7 ; 17)$ variant of acute promyelocytic leukaemia with clinical resistance to retinoic acid. Br. J. Haematol. 2014, 168, 904-908. [CrossRef]

100. Yu, Y.-P.; Liu, P.; Nelson, J.; Hamilton, R.L.; Bhargava, R.; Michalopoulos, G.; Chen, Q.; Zhang, J.; Ma, D.; Pennathur, A.; et al. Identification of recurrent fusion genes across multiple cancer types. Sci. Rep. 2019, 9, 1-9. [CrossRef] 
101. Franić, S.; Groen-Blokhuis, M.M.; Dolan, C.V.; Kattenberg, M.V.; Pool, R.; Xiao, X.; Scheet, P.A.; Ehli, E.A.; Davies, G.E.; van der Sluis, S.; et al. Intelligence: Shared genetic basis between Mendelian disorders and a polygenic trait. Eur. J. Hum. Genet. 2015, 23, 1378-1383. [CrossRef]

102. Schweppe, D.K.; Huttlin, E.; Harper, J.; Gygi, S.P. BioPlex Display: An Interactive Suite for Large-Scale AP-MS Protein-Protein Interaction Data. J. Proteome Res. 2018, 17, 722-726. [CrossRef]

103. Huttlin, E.L.; Bruckner, R.J.; Paulo, J.A.; Cannon, J.R.; Ting, L.; Baltier, K.; Colby, G.; Gebreab, F.; Gygi, M.P.; Parzen, H.; et al. Architecture of the human interactome defines protein communities and disease networks. Nature 2017, 545, 505-509. [CrossRef]

104. Huttlin, E.; Ting, L.; Bruckner, R.J.; Gebreab, F.; Gygi, M.P.; Szpyt, J.; Tam, S.; Zarraga, G.; Colby, G.; Baltier, K.; et al. The BioPlex Network: A Systematic Exploration of the Human Interactome. Cell 2015, 162, 425-440. [CrossRef]

105. Aguayo-Orozco, A.; Bois, F.Y.; Brunak, S.; Taboureau, O. Analysis of Time-Series Gene Expression Data to Explore Mechanisms of Chemical-Induced Hepatic Steatosis Toxicity. Front. Genet. 2018, 9, 396. [CrossRef]

106. Yang, W.; Li, Y.; He, F.; Wu, H. Microarray profiling of long non-coding RNA (lncRNA) associated with hypertrophic cardiomyopathy. BMC Cardiovasc. Disord. 2015, 15, 1-9. [CrossRef] [PubMed]

107. Yang, J.; Yan, R.; Roy, A.; Xu, D.; Poisson, J.; Zhang, Y. The I-TASSER Suite: Protein structure and function prediction. Nat. Methods 2015, 12, 7-8. [CrossRef] [PubMed]

108. Hodgkin, A.L.; Huxley, A.F. The components of membrane conductance in the giant axon of Loligo. J. Physiol. 1952, 116, 473-496. [CrossRef] [PubMed]

109. Kadir, L.A.; Stacey, M.; Barrett-Jolley, R. Emerging Roles of the Membrane Potential: Action Beyond the Action Potential. Front. Physiol. 2018, 9, 1661. [CrossRef] [PubMed] 